\title{
IL33 wt Allele
}

National Cancer Institute

\section{Source}

National Cancer Institute. IL33 wt Allele. NCI Thesaurus. Code C101775.

Human IL33 wild-type allele is located in the vicinity of 9p24.1 and is approximately $42 \mathrm{~kb}$ in length. This allele, which encodes interleukin-33 protein, is involved in cytokinemediated activation of inflammation. 